\title{
PENINGKATAN KEMAMPUAN MENULIS MELALUI MODEL PEMBELAJARAN ROUND CLUB PADA SDN 92 PALEMBANG
}

\author{
Dr. Sri Wahyu Indrawati, M.Pd \\ Univ. PGRI Palembang \\ Email :sriwahyuindrawati@gmail.com
}

\begin{abstract}
Abstrak:Model pembelajaran round club merupakan cara yang efektif bagi peserta didik dalam memberikan konstribusi mereka dan pandangan atau pemikiran anggota lain tentang tugas yang sedang mereka kerjakan. Model pembelajaran round club membantu peserta didik agar lebih aktif dalam proses pembelajaran dan tidak hanya terpaku pada satu arah. Artinya peserta didik akan lebih aktif dalam proses pembelajaran. Dalam pembelajaran dilakukan sebuah tes motivasi belajar untuk mengetahui tingkat keberhasilan dari pembelajaran tersebut. maka dari itu model pembelajaran round club dalam penyampaian ide-ide atau pendapat peserta didik serta peningkatan motivasi belajar dalam pembelajaran tematik. Round Club atau keliling kelompok merupakan model belajar mengajar yang bisa digunakan dalam semua mata pelajaran dan untuk semua tingkatan usia anak didik. Dalam kegiatan keliling kelompok masing-masing anggota dalam anggota kelompok mendapatkan kesempatan untuk memberikan kontribusi mereka dan mendengarkan pandangan dan pemikiran anggota yang lain. Dengan demikian penulis tertarik, membuat penelitian dengan judul, "PENINGKATAN KEMAMPUAN MENULIS MELALUI MODEL PEMBELAJARAN ROUND CLUB PADA SDN 92 PALEMBANG". Melalui Model Pembelajaran Round Club sangat efektif, dengan pengertian bahwa pola ini telah berhasil mengangkat kemampuan menulis siswa sehingga menurunkan akumulasi nilai $\mathrm{C}$ dan $\mathrm{E}$ baik berdasarkan indikator kinerja final line maupun berdasarkan hasil tes diagnostik. Berdasarkan indikator kinerja pada akhir Siklus II akumulasi nilai C dan E turun menjadi 15,79\% (tidak ada siswa mendapat nilai E) dari target 25,06\%. Dengan demikian, meskipun masih terdapat siswa yang berada pada nilai $\mathrm{C}$, secara keseluruhan dampak yang telah diberikan dalam Peningkatan Kemampuan Menulis Melalui Model Pembelajaran Round Club Pada SDN 92 Palembang sudah sangat signifikan.
\end{abstract}

Kata Kunci : Kemampuan Menulis, Model Pembelajaran Round Club

\section{PEBDAHULUAN}

Pendidikan merupakan tahapan perubahan sikap tingkah laku manusia maupun kelompok dalam pendewasaan dengan cara pelatihan atau pengajaran. Pendidikan berawal dari bahsa inggris education yang diambil dari educate (mendidik) yang berarti sebuah peningkatan. Dalam arti sempit education memiliki arti tahapan perbuatan untuk mendapatkan ilmu pengetahuan.

Senada dengan hal ini Omar Muhammad Al Toumy Al Syaebani mengartikan pendidikan adalah usaha terencana yang bertujuan untuk merubah sikapseseorang untuk kehidupan pribadinya maupun untuk masyarakat, begitu pula dalam merubah alam disekitarnya.

Pendidikan berjalan seirama dengan pembelajaran.Pembelajaran sendiri berasal dari kata belajar yang memiliki makna dan unsur utama dalam setiap tingkatan pendidikan. Berhasil atau tidaknya proses pendidikan terikat penting dengan suksesnya pembelajaran baik dirumah, disekolah maupun dalam masyarakat.Setidaknya seseorang dapat dikatakan terdidik bila telah mengalami proses pembelajaran dimanapun ia berada. Pembelajaran terhadap proses yang 
menciptakan suasana belajar dimana peserta didik benar benar terdorong untuk mempelajari keilmuan tertentu, sehingga tujuan pemebelajaran dapat tercapai.

Dalam pembelajaran kemampuan bebahasa sangat diperlukan karena bahasa dapat menentukan pola pikir seseorang, semakin bagus kemampuan seseorang dalam berbahasa berbanding lurus dengan kejelasan pikiranya.maka dapat disimpulkan melatih kemampuan berfikir sama dengan melatih keterampilan berbahasa yang bisa ditempuh melalui praktik dan banyaknya pelatihan.

Diantara kemampuan berbahasa yang harus dimiliki adalah menulis (writing). Kegiatan menulis yang produktif dan ekspresif ini juga mampu mengungkapkan pikiran atau gagasan sesorang kepada orang lain. Oleh karenanya kegiatan menulis harus dibiasakan sejak kecil yang mana kepekaan terhadap suatu peristiwa atau pengalaman dapat diasah melalui berbagai macam bentuk tulisan.Salah satunya adalah dengan menulis karangan narasi.

Berdasarkan pengamatan di SDN 92 Palembang serta wawancara pada guru wali kelas, didapati bahwa: 1) Masih banyak guru-guru menggunakan metode atau strategi mengajar tradisional dimana guru menerangkan suatu konsep dan siswa mendengar, mencatat dan membuat contoh sesuai dengan petunjuk atau perintah dosen sesuah itu selesai; 2) proses komunikasi pembelajaran yang terjadi saat ini cenderung komunikasi satu arah (dari dosen ke mahasiswa), hanya sesekali terjadi komunikasi dua arah;

3) proses belajar mengajar kelihatan sangat monoton dan membosankan serta tidak variatif dan relevan baik bagi dosen maupun siswa; 4) proses pembelajaran menulis saat ini kurang dan bahkan tidak menantang siswa untuk berpikir kritis, analitik, dan menciptakan kompetisi, serta tidak memotivasi mereka untuk berpikir independen terhadap suatu topik atau pokok bahasan dalam writing; 5) Siswa cenderung pasif dan tidak kreatif serta tidak dapat melakukan koreksi/pembenaran terhadap suatu data maupun konsep karena informasi cenderung didominasi oleh guru

Dengan demikian, secara umum dapat dikatakan akar masalah dari rendahnya kemampuan menulis dipengaruhi oleh metode pengajaran yang diterapkan oleh dosen. Padahal metode pengajaran sangat memegang peran penting atas keberhasilan siswa dalam prose pembelajaran. Berkaitan dengan metode pengajaran, Harmer (2003); Nunan (1995); Ann Raimes (1983) berpendapat bahwa mahasiswa belajar dan keberhasilan mahasiswa dipengaruhi oleh metode, teknik atau strategi yang digunakan oleh 
guru. Dengan demikian dapat disimpulkan secara sementara bahwa masalah utama yang menyebabkan rendahnya kemampuan menulis siswa adalah metode atau strategi atau pola pembelajaran atau pengajaran yang diterapkan oleh Guru.

Kenyataannya siswa mengalami banyak kesulitan dalam proses menulis sehingga kemampuan mereka masih rendah. Kesulitan dalam menulis mungkin disebabkan oleh menulis adalah kegiatan yang sangat kompleks. Bisa dikatakan bahwa menulis menduduki tempat pertama di antara empat kemampuan berbahasa. Hal ini memang wajar karena menulis melibatkan tiga hal utama, yaitu: 1) apa yang akan ditulis; 2) bagaimana menghubungkan apa yang dikatakan; 3) bagaimana mengekspresikan apa yang dikatakan. (Mariane dan Murcia, 1979); (Ann Raimes, 1983).

Pendapat di atas juga didukung oleh Roland (1989), Purwanto Ngalim (1986), dan Nuna (1995) bahwa menulis adalah kegiatan yang sangat kompleks dan rumit karena menulis memiliki komponen dan aturan yang harus diperhatikan dan dipenuhi untuk membuat suatu karangan akademik (academic writing) seperti sintaks, tata bahasa, pengorganisasian, kosa kata, isi, kemampuan berkomunikasi, peggunaan tanda baca, dan juga teknik menulis.

$$
\text { Oshima dan Hogue }
$$
mengatakan bahwa paragraf adalah bentuk unit organisasi dasar dalam tulisan dimana kelompok kalimat yang saling berhubungan tersebut membangun dan mengembangkan suatu ide utama. Sejalan dengan Oshima dan Hogue, Lynn (1987) menyebutkan bahwa paragraf adalah serangkaian kalimat yang menghubungkan satu unit pokok pikiran. Kemudian, Richard (1985) menambahkan bahwa paragraf adalah sejumlah kalimat yang mengembangkan satu ide pokok atau menerangkan dan memperluas satu pokok pikiran.

Sebuah paragraf akademik secara eksplisit mempunyai tiga struktur fisik, yaitu a) topic sentence, b) supporting sentences, dan c) concluding sentence. (Oshima dan Hogue, 1985); Lynn (1987). Disamping ketiga komponen di atas, sebuah paragraf yang baik juga harus mempunyai tingkat koherensi dan unity yang tinggi. Artinya, koherensi adalah semua kalimat harus saling berhubungan dan berkait dalam rangka mengembangkan ide pokok.

Koherensi tidak saja mengenai isi paragraf tetapi juga dalam konteks gramatikal bahasanya sendiri serta pilihan kata. Sedangkan, unity berarti sebuah paragraf menyajikan satu pikiran utama. Tetapi, jika ide itu sangat dekat mungkin sebuah paragraf mengandung dua pokok 
pikiran. Dalam penelitian ini, paragraf yang diajarkan adalah satu paragraf mengandung satu pokok pikiran.

Berdasarkan

permasalahan

tersebut, penelititi mencoba menerapkan model pembelajaran yang baru, mungkin dengan menerapkan model pembelajaran yang baru lebih memungkinkan peserta didik menjadi lebih aktif sehingga diharapkan motivasi belajar peserta didik meningkat dalam proses pembelajaran. Model pembelajaran tersebut adalah model pembelajaran Roun Club atau keliling kelompok.

Menurut Uma Sekaran dalam buku Sugiyono, kerangka berfikir merupakan model konseptual tentang bagaimana teori berhubungan dengan berbagai faktor yang telah diidentifikasi sebagai masalah yang penting. Dari uraian diatas dapat disimpulkan bahwa kerangka berfikir adalah garis besar atau gambaran singkat yang menunjukan hubungan antar variabel dalam suatu penelitian.

Model pembelajaran round club merupakan cara yang efektif bagi peserta didik dalam memberikan konstribusi mereka dan pandangan atau pemikiran anggota lain tentang tugas yang sedang mereka kerjakan. Model pembelajaran ini akan memudahkan peserta didik memahami tugas yang diberikan oleh guru, mereka akan lebih mengetahui tentang tugas tersebut, mereka akan saling memberikan pandangan dan pendapat mereka tentang hal tersebut.

Model pembelajaran round club membantu peserta didik agar lebih aktif dalam proses pembelajaran dan tidak hanya terpaku pada satu arah. Artinya peserta didik akan lebih aktif dalam proses pembelajaran. Dalam pembelajaran dilakukan sebuah tes motivasi belajar untuk mengetahui tingkat keberhasilan dari pembelajaran tersebut. maka dari itu model pembelajaran round club dalam penyampaian ide-ide atau pendapat peserta didik serta peningkatan motivasi belajar dalam pembelajaran tematik.

Round Club atau keliling kelompok merupakan model belajar mengajar yang bisa digunakan dalam semua mata pelajaran dan untuk semua tingkatan usia anak didik. Dalam kegiatan keliling kelompok masing-masing anggota dalam anggota kelompok mendapatkan kesempatan untuk memberikan kontribusi mereka dan mendengarkan pandangan dan pemikiran anggota yang lain.

Dengan demikian penulis tertarik, membuat penelitian dengan judul, "PENINGKATAN KEMAMPUAN MENULIS MELALUI MODEL PEMBELAJARAN ROUND CLUB PADA SDN 92 PALEMBANG” 


\section{METODE}

Dalam hal ini, peneliti menggunakan Quasi Eksperimen Desaign dengan alasan peneliti tidak dapat melakukan kontrol atau pengendalian variabel secara ketat atau penuh. Situasi kelas sebagai tempat perlakuan tidak memungkinkan pengontrolan yang sedemikian ketat. Jadi dalam hal ini peneliti dapat melakukan control variabel sesuai dengan keadaan atau kondisi yang ada.

Langkah-langkah yang digunakan dalam penelitian ini adalah:

1. Observasi pendahuluan

a. Peneliti menentukan pokok bahasan yang akan diteliti.

b. Peneliti menentukan populasi dan sampel penelitian sebanyak dua kelas. menentukan sampel pada penelitian ini peneliti menggunakan teknik Cluster Random Sampling (sampling acak kelompok). Cara penetuan sampel ini yaitu dengan menggunakan lot/kocokan seperti arisan. Dari ketiga kelas, kelas 2 dikocok dalam satu lot, kertas yang keluar pertama adalah sampel untuk kelas eksperimen dan kertas yang keluar kedua digunakan sebagai sampel kelas kontrol.

Tahap pelaksanaannya, penelitian dilakukan dalam dua kelas, dikelas eksperimen yang menggunakan model pembelajaran Round Club dan kelas control yang menggunakan metode pembelajaran Conventional Group .

\section{HASIL PENELITIAN}

\section{Siklus I}

Sebelum diberi tindakan selama berlangsungnya penelitian, siswa terlebih dahulu diberi tes diagnostik untuk mengetahui kemampuan awal mereka dalam menulis. Tabel berikut menunjukkan hasil tes tersebut.

Tabel 1. Kemampuan awal menulis siswa

\begin{tabular}{|c|l|c|c|}
\hline Nilai & \multicolumn{1}{|c|}{ Kategori } & Frekwensi & Persentase \\
\hline $90-100$ & Sangat Baik & 0 & 0,00 \\
\hline $80-89$ & Baik & 9 & 23,68 \\
\hline $70-79$ & Cukup & 27 & 71,05 \\
\hline $0-69$ & Sangat Kurang & 2 & 5,26 \\
\hline \multicolumn{2}{|c|}{ Jumlah } & 38 & 100 \\
\hline
\end{tabular}

Berdasarkan tabel 1 di atas, dapat dijelaskan bahwa sebagian besar kemampuan awal siswa $(71,05 \%)$ berada pada rentangan nilai $70-79$ dengan kategori Cukup sementara tidak satupun yang berada pada kategori Sangat Baik. Bila dilihat secara keseluruhan, maka kemampuan rata-rata awal siswa dalam 
menulis adalah berada pada tingkat Cukup yaitu dengan nilai rata-rata 76,02. Bila dilihat secara persentase prestasi mendapatkan nilai $\mathrm{A}$ dan $\mathrm{B}$, maka hanya $23,68 \%$ mahasiswa yang berada pada level itu, sedangkan sebesar $76,31 \%$ berada pada nilai $\mathrm{C}$ dan $\mathrm{E}$.
Setelah dilaksanakan Siklus I, kemampuan mahasiswa mengalami sedikit peningkatan. Tabel berikut memberikan data tentang progress yang diperoleh mahasiswa setelah dilaksanakan tes akhir Siklus I.

Tabel 2. Kemampuan menulis mahasiswa setelah Siklus I

\begin{tabular}{|c|l|c|c|}
\hline Nilai & \multicolumn{1}{|c|}{ Kategori } & Frekwensi & Persentase \\
\hline $90-100$ & Sangat Baik & 0 & 0,00 \\
\hline $80-89$ & Baik & 22 & 57,90 \\
\hline $70-79$ & Cukup & 15 & 39,47 \\
\hline $0-69$ & Sangat Kurang & 1 & 2,63 \\
\hline \multicolumn{2}{|l|}{ Jumlah } & 38 & 100 \\
\hline
\end{tabular}

Meskipun secara rata-rata kemampuan menulis siswa secara signifikan mengalami kenaikan $(78,16)$, kenaikan ini belum mampu mengangkat kategori nilai mahasiswa yang masih berada pada tingkat Cukup. namun terjadi perubahan positif dari sisi kategori nilai. Siswa yang mendapatkan nilai Baik telah meningkat dari hanya 9 orang menjadi 22 orang $(57,89 \%)$, sedangkan hanya 1 orang $(2,63 \%)$ mahasiswa mendapatkan nilai sangat Kurang.

Dari data ini kemudian dapat dilihat terjadi kenaikan persentase nilai A dan B (meskipun belum ada yang memperoleh nilai A) menjadi 57,90\% dari sebelumnya yang hanya $23,68 \%$. Konsekwensinya, persentase akumulasi nilai $\mathrm{C}$ dan $\mathrm{E}$ menjadi menurun menjadi sebesar $42,10 \%$.
Persentase nilai $\mathrm{C}$ dan $\mathrm{E}$ ini masih sangat tinggi dan menunjukkan bahwa masih banyak mahasiswa yang mengalami kesulitan dalam menulis. Setelah melakukan evaluasi terhadap siklus I, dan berdasarkan catatan-catatan yang dilakukan selama melaksanakan penelitian, beberapa masalah berikut dapat teridentifikasi:

1. Siswa masih merasa canggung dengan pola yang diterapkan, terutama karena mereka belum terbiasa memberi koreksi apalagi secara tertulis terhadap hasil tulisan temannya;

2. Siswa menyampaikan hasil koreksi dengan membacakannya langsung dari kertas hasil koreksi; mereka tidak membuatnya ke dalam bentuk media tertentu.

3. Kegiatan di sekolah untuk mata pelajaran Bahasa Indonesia dalam hal 
menulis mulai diajarkan secara langsung mengenal genre di mana siswa belum terbiasa untuk melihat genre berdasarkan unsur-unsur leksikogramatika dan struktur skematiknya. Hal ini berakibat, perlunya waktu bagi mereka untuk mengubah mindset dari tradisional ke fungsional.

\section{Siklus II}

Setelah berakhirnya Siklus I, penelitian dilanjutkan dengan Siklus II, yang merupakan bagian akhir penelitian. Perbaikan-perbaikan dilakukan untuk mendapatkan proses pembelajaran yang lebih baik. Dalam siklus ini siswa dimotivasi untuk tidak lagi merasa canggung memberikan koreksi karena kegiatan tersebut tidak akan merugikan dan merupakan bagian dari proses pembelajaran. Kemudian, ketika melakukan koreksi sebuah pekerjaan mahasiswa tidak lagi melakukan secara individual namun dalam kelompok dan hasilnya dipresentasikan dalam bentuk yang berbeda. Sebagian kelompok membuat hasil koreksi dalam bentuk PowerPoint sementara sebagian lainnya berbentuk Poster. Hal ini memberikan dampak yang sangat positif dan membuat banyak siswa ingin terlibat di dalamnya.

Setelah dilakukan tes untuk mengetahui tingkat keberhasilan siswa, diperoleh data sebagai berikut:

Tabel 3. Kemampuan menulis siswa setelah siklus II

\begin{tabular}{|c|l|c|c|}
\hline Nilai & \multicolumn{1}{|c|}{ Kategori } & Frekwensi & Persentase \\
\hline $90-100$ & Sangat Baik & 7 & 18,42 \\
\hline $80-89$ & Baik & 25 & 65,79 \\
\hline $70-79$ & Cukup & 6 & 15,79 \\
\hline $0-69$ & Sangat Kurang & 0 & 0,00 \\
\hline \multicolumn{2}{|l|}{ Jumlah } & 38 & 100 \\
\hline
\end{tabular}

Data tabel 3 ini menunjukkan bahwa terjadi peningkatan yang cukup signifikan dalam hasil belajar menulis siswa. Pada fase ini, sebanyak $7(18,42 \%)$ mahasiswa telah berhasil mendapatkan nilai A dari tidak ada sama sekali. Kemudian, untuk nilai $\mathrm{B}$ juga mengalami peningkatan menjadi $65,79 \%$, sedangkan nilai $\mathrm{C}$ menurun menjadi $15,79 \%$ dan tidak seorangpun siswa yang mendapatkan nilai E. Peningkatan juga dapat dilihat dari rata- rata nilai mahasiswa yang berada pada rentangan Baik, yaitu 83,58.

Dengan hasil ini, akumulasi nilai $\mathrm{C}$ dan E telah menurun cukup drastis $(15,79 \%)$, dengan tidak ada satu orangpun siswa yang mendapatkan nilai E. Bila dilihat dari data kemampuan awal yang menjadi indikator sebagai titik tolak penelitian ini, hasil akhir yang diperoleh siswa sudah dapat memenuhi bahkan melebihi indikator kinerja yang diasumsikan sebelumnya, yaitu dengan 
menurunnya persentase nilai $\mathrm{C}, \mathrm{D}$, dan $\mathrm{E}$ (hanya $\mathrm{C}$ dan $\mathrm{E}$ pada KBK).Untuk lebih

Berdasarkan angket yang disebarkan ke siswa untuk mendapatkan persepsi mereka tentang Peningkatan Kemampuan Menulis Melalui Model Pembelajaran Round Club Pada SDN 92 Palembang.Diperoleh Sejumlah data yang berkaitan dengan penelitian ini. Peningkatan Kemampuan Menulis Melalui Model Pembelajaran Round Club Pada SDN 92 Palembang memberikan dampak yang sangat positif bagi siswa dalam belajar. Tidak seorangpun siswa menyatakan kurang setuju atau tidak setuju terhadap pernyataan-pernyataan yang disampaikan.

Siswa merasa senang dengan pendekatan pembelajaran semacam ini yang dinyatakan dengan tingginya akumulasi persentase yang menyatakan sangat setuju dan setuju $(92,1 \%)$ sedangkan sisanya menyatakan cukup. Peningkatan Kemampuan Menulis Melalui Model Pembelajaran Round Club Pada SDN 92 Palembang juga dapat meningkatkan motivasi belajar siswa yang juga sebesar 92,1\%. Sebanyak 86,84\% siswa menyebutkan bahwa Peningkatan Kemampuan Menulis Melalui Model Pembelajaran Round Club Peningkatan Kemampuan Menulis Melalui Model Pembelajaran Round Club mereka yakini spesifik, dapat disebutkan bahwa final line yang diasumsikan adalah sebesar 25,06\%

dapat meningkatkan daya pikir, dan bahkan daya berpikir kritis $(97,4 \%)$. Selain itu Peningkatan Kemampuan Menulis Melalui Model Pembelajaran Round Club dapat mengurangi salah pengertian dalam struktur, pilihan kata, organisasi, dsb. $(94,74 \%)$. Dengan pola pembelajaran yang diterapkan, terutama ketika mereka harus membuat laporan hasil koreksi dalam bentuk yang berbeda membuat siswa percaya bahwa Peningkatan Kemampuan Menulis Melalui Model Pembelajaran Round Club dapat membantu mereka kreatif $(86,8 \%)$.

Dan hal penting lainnya adalah bahwa sebanyak 92,1\% menyatakan bahwa Peningkatan Kemampuan Menulis Melalui Model Pembelajaran Round Club dapat memotivasi mereka untuk bukan saja belajar namun aktif di dalamnya. Namun, meskipun persentase yang menyatakan bahwa Peningkatan Kemampuan Menulis Melalui Model Pembelajaran Round Club dapat membantu mereka memahami konsep-konsep dalam writing (84,2\%), sebesar $15,8 \%$ masih belum dapat mempelajari konsep dengan cara ini.

Dari seluruh siswa, didapati bahwa sebanyak $71,05 \%$ menyatakan mereka belum pernah mengenal Peningkatan Kemampuan Menulis Melalui 
Model Pembelajaran Round Club sebelumnya.

\section{PEMBAHASAN}

Menulis sebagai salah satu skill bahasa sering sekali menjadi masalah yang rumit bagi siswa karena di dalamnya tidak hanya tentang penyampaian gagasan belaka namun harus memperhatikan aspekaspek bahasa lainnya. Menulis membutuhkan pengetahuan dan pemahaman tentang struktur, kosa kata, organisiasi, dsb., disamping ide yang ingin disampaikan. Dalam penelitian ini, ditemukan bahwa siswa mengalami kesulitan dalam menulis pada saat sebelum dilaksanakan perlakuan, yang terbukti dengan tingginya akumulasi nilai $\mathrm{C}$ dan $\mathrm{E}$.

Diperkenalkannya Peningkatan Kemampuan Menulis Melalui Model Pembelajaran Round Club dalam pembelajaran menulis telah memberikan dampak yang sangat signifikan pada perubahan pengetahuan dan keterampilan siswa. Menurut catatan selama masa penelitian, pada awalnya siswa memang merasa sangat canggung dan memiliki hambatan psikologis ketika mereka harus mengoreksi dan mencoret-coret hasil tulisan temannya.

Mereka ragu-ragu untuk melakukan koreksi apalagi mereka merasa bahwa belum tentu hasil koreksi mereka benar.
Mereka takut justru hasil koreksi menyalahkan apa yang sudah benar.

Pada siklus I ini, seorang siswa melakukan koreksi terhadap satu orang siswa saja dan kemudian sebagian dari mereka diminta untuk menyampaikan hasil perbaikan dengan membaca dan menuliskan sebagian hasil koreksi di papan tulis. Di sini tampak bahwa mereka masih merasa terpaksa untuk melakukannya karena hambatan psikologis yang dialami. Sebagai akibatnya, nilai rata-rata kelas tidak beranjak cukup tinggi dari nilai tes diagnostik meskipun telah terdapat penurunan pada akumulasi nilai $\mathrm{C}$ dan $\mathrm{E}$ $(42,10 \%)$.

Melihat kondisi ini, pada siklus II dilakukan beberapa perbaikan. Pertama, guru meyakinkan siswa bahwa kegiatan yang mereka lakukan hanya bagian dari proses pembelajaran. Salah atau benar bukan menjadi hal yang utama karena secara bersama-sama mereka harus dapat mempelajari konsep-konsep. Kedua, cara penyampaian hasil koreksi diubah, yaitu dengan menggunakan media PowerPoint dan Poster dan siswa tidak lagi bekerja secara individu untuk mengoreksi sebuah pekerjaan namun dalam kelompok.

Sebagai hasilnya, mahasiswa merasa lebih leluasa dan terbuka untuk menyampaikan pemikirannya dalam melakukan koreksi, kemudian semangat team work juga terbanguan di antara 
mereka. Mereka membuat koreksi dengan lebih baik, dan sanggahan-sanggahan selama mereka presentasi pun semakin banyak. Di sini terlihat bahwa mahasiswa mulai mengkritisi bukan hanya pada hasil pekerjaan namun juga pada tampilan pada poster misalnya yang mereka anggap tidak memadai. Hal ini disebabkan karena adanya kelompok yang membuat poster sangat kecil sehingga tidak terlihat oleh mereka.

Pada akhir presentasi guru kemudian menyampaikan bahwa untuk perbaikan, pada pertemuan berikutnya kelompok yang membuat poster dapat menyediakan tiga poster yang sama yang dapat ditempelkan pada dinding-dinding kelas dan membiarkan teman-temannya untuk melihat secara langsung layaknya sebuah pameran. Sambil mereka mengamati dan memeriksa hasil koreksi, kelompok presentasi dapat menyampaikan penjelasan atas koreksi yang mereka buat.

Perbaikan pada siklus II ini memberikan pengaruh yang sangat baik pada hasil belajar mahasiswa, terbukti dari peningkatan yang diperoleh pada rata-rata kelas yang mencapai angka 83,58, yang sudah berada pada rentang nilai $B$. Persentase nilai $\mathrm{C}$ dan $\mathrm{E}$ juga menurun secara drastis hingga mencapai $15,79 \%$. Dan bahkan tidak seorang mahasiswa pun yang mendapat nilai E. Sehingga, indikator kinerja pada final line yang telah ditetapkan $(25,06 \%)$ dapat dicapai dan bahkan terlampaui.

Hal ini sangat jelas dipengaruhi oleh suasana dan pendekatan yang dilakukan ketika proses pembelajaran berlangsung, di mana mahasiswa merasa senang dengan pola yang diterapkan $(92,1 \%)$ dan sisanya merasa cukup senang.

Penurunan akumulasi nilai $\mathrm{C}$ dan $\mathrm{E}$ ini juga disebabkan oleh fakta bahwa mahasiswa yakin pendekatan yang dilakukan membangkitkan motivasi $(92,1 \%)$ dan meningkatkan daya pikir kritis mereka.(97,4\%). Hal ini tergambar selama proses pembelajaran berlangsung, di mana siswa berupaya untuk menyampaikan pikirannya secara terbuka dan mempertahankan pendapat serta menerima pendapat orang lain.

Namun, sebagai catatan memang terdapat siswa yang menganggap bahwa pendapatnya selalu benar, namun dengan penjelasan yang diberikan oleh guru pada akhir pertemuan pemahaman dan kesalahan yang terjadi selama proses pembelajaran dapat diluruskan. Selain itu, siswa juga merasa bahwa dengan bentukbentuk laporan hasil koreksi yang beragam mereka mendapati bahwa kreatifitas sangat diperlukan untuk membuat tampilan hasil koreksi itu benar-benar menarik perhatian. Dengan demikian, mereka terpacu untuk terus berpikir sekreatif mungkin dalam penyajiannya. 
Sebagai kesimpulan dari data-data dan catatan yang ada, Peningkatan Kemampuan Menulis Melalui Model Pembelajaran Round Club Pada SDN 92 Palembang benar-benar mampu memberikan dampak yang sangat positif terhadap perkembangan dan kemajuan kemampuan menulis siswa.

Selain dari pembelajaran konsepkonsep menulis siswa juga merasa relaks atau tidak tegang selama pembelajaran serta mereka mampu mengembangkan daya pikir dan kreatifitas mereka. Kemudian, keterbukaan dalam menyampaikan pendapat dan mempertanyakan hasil koreksi memberikan peluang bagi siswa untuk mengembangkan keterampilan berkomunikasi dan bernegosiasi serta lebih transparan dalam mengemukakan pikiran.

KESIMPULAN

Beberapa kesimpulan yang berkenaan dengan hasil penelitian dapat diambil. Pertama, Peningkatan Kemampuan Menulis Melalui Model Pembelajaran Round Club Pada SDN 92 Palembang sangat efektif, dengan pengertian bahwa pola ini telah berhasil mengangkat kemampuan menulis siswa sehingga menurunkan akumulasi nilai $\mathrm{C}$ dan $\mathrm{E}$ baik berdasarkan indikator kinerja final line maupun berdasarkan hasil tes diagnostik. Berdasarkan indikator kinerja pada akhir Siklus II akumulasi nilai $\mathrm{C}$ dan
E turun menjadi $15,79 \%$ (tidak ada siswa mendapat nilai E) dari target $25,06 \%$. Dengan demikian, meskipun masih terdapat siswa yang berada pada nilai C, secara keseluruhan dampak yang telah diberikan dalam Peningkatan Kemampuan Menulis Melalui Model Pembelajaran Round Club Pada SDN 92 Palembang sudah sangat signifikan.

Berdasarkan hasil penelitian ini, beberapa hal dapat disarankan kepada pihak-pihak baik sebagai pengajar maupun pengambil kebijakan. Pertama, dengan bukti bahwa Peningkatan Kemampuan Menulis Melalui Model Pembelajaran Round Club Pada SDN 92 Palembang efektif meningkatkan kemampuan menulis siswa para pengajar baik guru dan dosen dapat memilih pendekatan ini dalam pembelajaran.

\section{DAFTAR PUSTAKA}

Brown, Douglas H. 1980. Pinciples of Language Learning and Teaching. Englewood Cliff, New Jersey: Prentice Hall. 2001. Teaching by Principles: An Alternative Approach to Language Pedagogy. San Fransisco: Pearson Education Limited.

Harmer, Jeremy. 2001. How to Teach Writing. Essex: Stenton Associates. . 2003. The Practice of Language Teaching. England: Pearson Education Limited. 
Huda, Miftahul, Cooperative Learning (Yogyakarta: Pustaka Pelajar, 2017.

Jurnal Skripsi. Rizky Ayu Pratiwi, "Meningkatkan Motivasi Belajar Siswa Dengan Menggunakan Model Pembelajaran Round Club Pada Mata Pelajaran IPA Dikelas IV SD Negeri 101771 Tembung T.A 2016/2017”, Universitas Negeri Medan, Fakultas Pendidikan, 2017.

Jurnal skripsi. Nurleli Sabeth, "Pengaruh Penerapan Modl Pembelajaran Kooperatif Tipe Keliling Kelompok Terhadap Hasil Dan Minat Belajar Matematika Siswa Sekolah Menengah Pertama Negeri 4 Minas Kec. Minas Kab. Siak”, UIN Suska Riau, FTK, 2013.

Jurnal Skripsi. Elfira Nurelina, "Penerapan Model Pembelajaran Kooperatif Tipe Keliling Kelompok Untuk Meningkatkan Prestasi Belajar Siswa Pada Pokok Bahasa Hidrokarbon Dikelas X SMA Muhammadiyah 1 Pekan Baru”,UIN Suska Riau, FTK, 2014.

Jurnal Skripsi. Nikmatul Khoeriyah, "Keefektifan Strategi Keliling Kelompok Dalam Pembelajaran Menulis Pantun Ssiswa Kelas VII SMPN 2 Ngemplak, Sleman",Pendidikan Bahaasa dan Sastra Indonesia, Fakultas Bahasa dan Seni Universitas Negeri Yyogyakarta, 2013

Khoiri, Ahmad, dkk, "Penumbuhan Karakter Islami Melalui Pembelajaran Fisika Berbasis Integrasi Sains Islam”, Jurnal Keguruan dan Ilmu Tarbiyah, Vol. 2, No. 1, (Juni 2017).

Lie, Anita, Cooperative Learning (Jakarta: PT Grasindo, 2014.
Genre Writing Workshop. http//www.handbooks.uts.edu.au/su bject

Langan, John. 2004. College Writing Skills with Reading. New York: McGraw Hill

Larsen-Freeman, D. Dan M.H. Long. 1991. Introduction to Second Language Acquisition Research. New York: Longman Inc.

Oshima A, dan A. Hogue. 1999. Writing Academic English. New York: Pearson Education Limited.

Reid, M. Joy. 1993. Teaching ESL Writing. Wyoming; Prentice Hall Regent.

Tarigan, Henry Guntur.1986. Menulis Sebagai Suatu Ketrampilan Berbahasa. Bandung: Angkasa. 